J. Lake Sci. (湖泊科学), 2020, 32(4): 1165-1176

DOI 10. 18307/2020. 0423

(C) 2020 by Journal of Lake Sciences

\title{
白格堰塞湖对金沙江水沙及梯级水库运行的影响"
}

\author{
朱玲玲**, 李圣伟, 董炳江, 许全喜, 袁 晶 \\ (长江水利委员会水文局,武汉 430010)
}

\begin{abstract}
摘 要: 2018 年金沙江上游白格滑坡造成了近百年来最为严重的干流堵江事件,堰塞湖的形成和溃决给下游金沙江干流 河道的水沙条件及梯级水电站运行造成影响. 本文依据堰塞湖附近临时观测和金沙江干流河道控制性水文站的相关资 料, 研究堰塞体泄流对下游河道水沙输移的影响, 同时结合梯级水库调度情况, 计算了梯级水库的拦沙量. 结果表明, 堰 塞湖溃决在金沙江中游形成了超历史的水沙过程, 金沙江中游梯级电站开展应急调度后, 堰塞湖溃决造成的特大洪水被 削减为一般洪水. 金沙江中游梯级梨园、阿海和金安桥电站累积拦截泥沙约 1400 万 $\mathrm{t}$, 龙开口、鲁地拉和观音岩电站共计 拦截泥沙约 43 万 $\mathrm{t}$, 滑坡体产生的泥沙仍有约 74\% 滞留在堰塞体附近. 若滑坡体泥沙全部输移至金沙江中游梯级水库 内,梨园电站的有效库容极有可能不满足水库所需调节库容的要求.
\end{abstract}

关键词: 白格堰塞湖; 金沙江;水沙条件;梯级电站

\section{Effect of Baige landslide-dammed lake on runoff and sediment of the Jinsha River and operation of cascade reservoirs*}

\author{
ZHU Lingling ** , LI Shengwei, DONG Bingjiang, XU Quanxi \& YUAN Jing \\ (Bureau of Hydrology, Changjiang Water Resources Commission, Wuhan 430010, P.R.China)
}

\begin{abstract}
Baige landslide occurred in the upstream of Jinsha River in October 10, 2018 caused the most serious river blockage event in the recent hundred years. Formation and breaking of the Baige landslide-dammed lake (BLDL) had unknown effects on water and sediment conditions and the operation of cascade hydropower stations in the main stream of the downstream Jinsha River. Based on the observational data of the temporary gauge station near the BLDL and the controlled hydrological stations in the main trunk of Jinsha River, the effects of BLDL on water and sediment conditions in the middle and lower Jinsha River are studied. Combining with the operation of cascade reservoirs before and after the breaking of the landslide-dammed lake, the sediment retention amount of cascade reservoirs is estimated. The results showed the breaking of the BLDL formed a super-historical hydrograph of water and sediment in the middle Jinsha River. After the emergency regulation of cascade reservoirs in the middle Jinsha River, the extraordinary flood caused by the outbreak of the BLDL was reduced to a normal flood. Nearly $26 \%$ of the sediment generated by landslides is transported and deposited in cascade reservoirs in the middle Jinsha River. Among them, the Liyuan, Ahai, and Jinanqiao hydropower stations intercepted about 14 million tons of sediment, while Longkaikou, Ludila, and Guanyinyan hydropower stations intercepted about 0.43 million tons of sediment. About $74 \%$ of the landslide-induced sediment remains near the Baige barrier. Given that all the sediments generated by the Baige landslide are transported into the cascade reservoirs along the middle Jinsha River, the effective reservoir capacity of Liyuan hydropower station will probably not meet the requirement of the reservoir regulating capacity.
\end{abstract}

Keywords: Baige landslide-dammed lake; Jinsha River; water and sediment conditions; cascade reservoir

长江干流通天河在楚玛尔河汇人后, 自直门达水文站至四川省宜宾市即江口称为金沙江. 其中, 巴塘至 石鼓为上游, 石鼓至攀枝花为中游, 攀枝花至岷江口为下游. 向家坝水电站运行前, 金沙江出口控制站屏山

* 2019-07-18 收稿;2019-11-22 收修改稿.

国家重点基础研发计划项目 (2016YFC0402301)、三峡工程泥沙重大问题研究项目 (ZZ2018013001F) 和中国长江 三峡集团有限公司科研项目 (0704166) 联合资助.

** 通信作者;E-mail: Zhull1012@ foxmail.com. 
站多年平均 (1955-2011 年) 径流量和输沙量分别为 1430 亿 $\mathrm{m}^{3}$ 和 2.35 亿 $\mathrm{t}$, 分别占同期长江中游宜昌站的 $33.6 \%$ 和 $55.7 \%$, 泥沙占比尤为显著, 是长江流域泥沙最重要的来源 ${ }^{[1-2]}$. 金沙江下游屏山站多年平均含沙量 为 $1.64 \mathrm{~kg} / \mathrm{m}^{3}$, 大于长江干流中游宜昌站的 $0.989 \mathrm{~kg} / \mathrm{m}^{3}$ 及产沙量较大的一级支流嘉陵江 $\left(1.56 \mathrm{~kg} / \mathrm{m}^{3}\right)$ 和乌 江 $\left(0.497 \mathrm{~kg} / \mathrm{m}^{3}\right)$ 等. 地质构造和地层岩性因素是影响流域产沙的主要原因之一. 金沙江地处干热河谷, 流 域特殊的自然环境, 是造成其水土大量流失的先决条件 ${ }^{[3]}$. 起伏变化巨大的流域地形以及其破碎丰富的岩 石、碎屑, 孕育了可大量流失的松散物质, 在较大重力分力及暴雨促发动力的作用下, 泥沙以滑坡、泥石流、 崩塌等方式,汇人流域干、支流, 是金沙江输沙量偏大的重要因素 ${ }^{[4]}$.

2018 年 10 月 10 日和 11 月 3 日, 在大量强降雨及持续降雨作用下, 西藏昌都市江达县波罗乡白格村日 安组先后发生 2 次大型库岸岩质滑坡, 总方量约 3380 万 $\mathrm{m}^{3}$, 滑坡体迅速形成长约 $270 \mathrm{~m}$ 、可见高近 $60 \mathrm{~m}$ 的 堰塞坝, 阻断金沙江干流, 形成堰塞湖 ${ }^{[5-6]}$ ( 以下简称白格堰塞湖), 严重威胁上、下游人民群众生命财产安 全. 两次白格堰塞湖险情先后经自然和人工泄流后解除, 最大下泄流量分别达到 10000 和 $31000 \mathrm{~m}^{3} / \mathrm{s}^{[7]}$ ( 万 年一遇洪水), 大洪水同时挟带滑坡体泥沙和河道河床上的泥沙往下游输移, 下游巴塘站先后出现 21.6、42.0 $\mathrm{kg} / \mathrm{m}^{3}$ 的沙峰过程, 高含沙洪水到达金沙江中游后, 经梨园、阿海等梯级电站的联合调度和拦蓄, 洪峰大幅削 减 ${ }^{[8]}$, 泥沙也被大量拦截. 堰塞湖事件发生以来, 先后有学者就白格滑坡体产生机制和发展趋势、堰塞湖应 急监测、泄流方案论证及金沙江中游梯级水库应急调度等内容开展了研究 ${ }^{[5-10]}$, 对堰塞湖险情解除中的技术 问题及其金沙江防洪安全影响的评估有相对全面的总结. 金沙江作为长江流域最重要的水沙来源, 其突发 事件对于水沙情势的影响备受关注, 同时金沙江上、中、下游规划和开发了多级大型梯级电站 ${ }^{[11]}$, 水沙条件 突变会影响电站的建设、运行及使用寿命等 ${ }^{[12]}$, 目前关于该类问题尚未开展研究工作.

本文通过收集白格堰塞体附近、上下游河道控制性水文站、下游河道固定观测断面以及金沙江上、中、 下游梯级电站建设和运行等资料, 分析了高含沙洪水传播过程及金沙江中下游水沙的变化特征,估算了梯 级水库的拦沙量, 综合研究了白格堰塞湖事件对于金沙江上、中、下游水沙及梯级电站建设及运行的影响, 可为金沙江上、中、下游梯级电站的建设和运行提供数据基础. 此外, 研究对比分析了堰塞湖自然和人工泄 流条件下的下游河道水沙沿程输移特征, 有助于进一步丰富和完善溃坝洪水传播及水沙输移的模拟计算.

\section{1 金沙江白格堰塞湖险情}

2018 年 10 月 10 日 22 时 06 分, 西藏自治区江达县波罗乡白格村发生山体滑坡, 阻断金沙江干流形成 堰塞湖, 堰顶垭口高程为 $2931 \mathrm{~m}$ (白格堰塞湖地理位置见图 1). 2018 年 10 月 13 日凌晨 0 时 45 分左右, 滑 坡坝漫顶溢流后自然泄洪, 逐渐冲刷形成泄流槽, 最大下泄流量约 $10000 \mathrm{~m}^{3} / \mathrm{s}$. 堰塞湖水位持续下降,截至 10 月 16 日堰塞水位由 $2915.1 \mathrm{~m}$ 下降至 $2894.60 \mathrm{~m} .11$ 月 3 日 17 时 40 分, 右岸山体再次发生滑坡,形成二次 堰塞堵江断流, 堰塞体顺河长约 $270 \mathrm{~m}$, 横河宽约 $580 \mathrm{~m}$, 高出原河道泄流槽 $73 \sim 77 \mathrm{~m}$, 比首次堰塞湖堰顶高 出约 $35 \mathrm{~m} .11$ 月 8 日起, 通过 3 天连续开挖, 形成一条长 $220 \mathrm{~m}$ 的倒梯形导流槽. 11 月 12 日 5 时, 堰塞湖水 位涨至导流槽底高程 $2952.5 \mathrm{~m}, 13$ 日 13 时 45 分, 堰塞湖坝前水位达到最高值 $2956.4 \mathrm{~m}$, 总涨幅 $64.0 \mathrm{~m}$, 对应蓄 水量 5.78 亿 $\mathrm{m}^{3}, 18$ 时堰塞坝溃决达到洪峰流量 $31000 \mathrm{~m}^{3} / \mathrm{s} .11$ 月 15 日 8 时, 堰塞湖人库流量 $507 \mathrm{~m}^{3} / \mathrm{s}$, 出库 流量 $529 \mathrm{~m}^{3} / \mathrm{s}$, 出人库水量平衡, 水位稳定, 险情解除.

据邓建辉等对此次滑坡时间产生的原因及机制研究, 白格滑坡地处金沙江缝合带,岩性为元古界熊松 群片麻岩组,具有多期、多次变形与变质特点, 糜棱岩化和蚀变均很严重 ${ }^{[5]} .2018$ 年及此前 2 年里, 滑坡所在 的江达县降雨量急剧增加, 常有大量强降雨及持续降雨过程, 在长期重力、降雨和地下水的综合影响下, 山 体产生累积时效变形 ${ }^{[6]}$,且白格滑坡存留的变形区仍有再次滑塌和堵江的风险 ${ }^{[5-6]}$.

\section{2 堰塞湖泄流时洪峰、沙峰传播过程}

\section{1 第一次泄洪期 (自然)}

白格堰塞湖第一次泄流为自然漫溢过流, 泄流期间白格至石鼓段洪峰和沙峰传播过程连续性较好. 2018 年 10 月 13 日 6 时堰塞湖出现最大下泄流量 $10000 \mathrm{~m}^{3} / \mathrm{s}$, 根据观测, 下游 $190 \mathrm{~km}$ 的巴塘站 13 日 14 时 出现洪峰 $7850 \mathrm{~m}^{3} / \mathrm{s}$, 同时出现 $21.6 \mathrm{~kg} / \mathrm{m}^{3}$ 的沙峰, 含沙量大于 $5.0 \mathrm{~kg} / \mathrm{m}^{3}$ 的水流过程持续约 $14 \mathrm{~h}$; 下游 590 


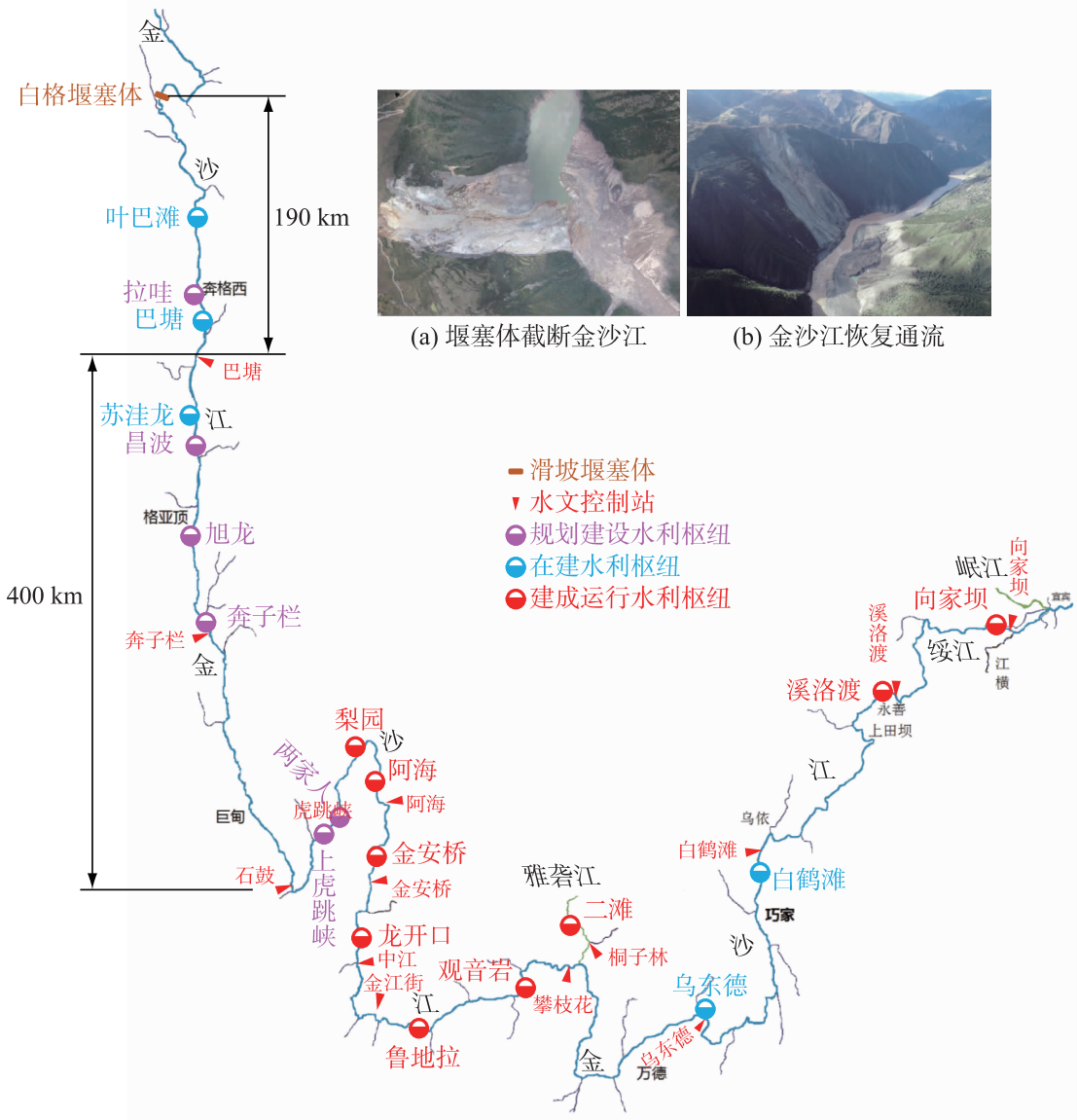

图 1 白格堰塞湖地理位置及金沙江水文站网和梯级电站分布

Fig.1 Location of BLDL and distribution of hydrological stations and cascade reservoirs in the Jinsha River

$\mathrm{km}$ 的石鼓站 15 日 0 时出现 $5210 \mathrm{~m}^{3} / \mathrm{s}$ 的洪峰, 15 日 2 时出现 $11.6 \mathrm{~kg} / \mathrm{m}^{3}$ 的沙峰, 沙峰稍稍滞后洪峰, 且沙 峰峰值有所坦化, 含沙量大于 $5.0 \mathrm{~kg} / \mathrm{m}^{3}$ 的过程持续约 $16 \mathrm{~h}$ (表 1、图 2). 主要受上游来流和河道上一时段沉 积的泥沙不断补给作用, 石鼓站高含沙量过程持续时间较巴塘站偏长. 综合来看, 白格堰塞湖自然泄流期 间, 堰塞体下游河道的洪峰和沙峰几乎同步传播, 洪峰传播速度沿程递减, 堰塞湖泄流洪峰传播至巴塘站的

表 1 白格堰塞湖泄流后沿程洪峰、沙峰特征值统计 *

Tab.1 Characteristic values of flood peaks and sand peaks after the discharge of Baige landslide-dammed lake

\begin{tabular}{ccccc}
\hline 次序 & 项目 & 白格(临时) & 巴塘 & 石鼓 \\
\hline 第一次泄流 & 洪峰大小 $/\left(\mathrm{m}^{3} / \mathrm{s}\right)$ & 10000 & 7850 & 5210 \\
(自然泄流期) & 洪峰峰显时间 & 10 月 13 日 6 时 & 10 月 13 日 14 时 & 10 月 15 日 0 时 \\
& 沙峰大小 $\left(\mathrm{kg} / \mathrm{m}^{3}\right)$ & $/$ & 21.6 & 11.6 \\
& 沙峰峰显时间 & $/$ & 10 月 13 日 14 时 & 10 月 15 日 2 时 \\
第二次泄流 & 洪峰大小 $\left(\mathrm{m}^{3} / \mathrm{s}\right)$ & 31000 & 21200 & 8380 \\
$($ 人工泄流期 $)$ & 洪峰峰显时间 & 11 月 13 日 18 时 & 11 月 14 日 1 时 & 11 月 15 日 8 时 \\
& 沙峰大小 $\left(\mathrm{kg} / \mathrm{m}^{3}\right)$ & $/$ & 42.0 & 28.5 \\
& 沙峰峰显时间 & $/$ & 11 月 14 日 0 时 & 11 月 15 日 2 时 \\
\hline
\end{tabular}

*巴塘站位于白格下游约 $190 \mathrm{~km}$,石鼓站位于白格下游约 $590 \mathrm{~km}$; 白格无临时测站,因此/表示无数据. 
速度约 $23.7 \mathrm{~km} / \mathrm{h}$, 自巴塘站传播至石鼓站的速度约为 $11.8 \mathrm{~km} / \mathrm{h}$, 速度减小一半; 堰塞湖水体下泄时挟带的 泥沙一部分在下游河道内沉积, 按控制站 10月 13-15 日输沙总量的差值统计, 沉积在巴塘至石鼓河段的泥 沙约有 400 万 $\mathrm{t}$, 另一部分则输送至金沙江中游水库内.

石鼓下游水流逐级进人金沙江中游梯级水库群. 此前, 梨园、阿海和金安桥水库共腾出近 3 亿 $\mathrm{m}^{3}$ 库容接 纳堰塞湖洪水 ${ }^{[8]}$, 因而洪峰过程经梨园和阿海电站调蓄后, 阿海电站下游的阿海水文站 15 日、16 日平均流 量下降至 $2560 、 2630 \mathrm{~m}^{3} / \mathrm{s}$, 较正常情况下的 10 月平均流量略偏大; 再经金安桥电站调蓄后, 至攀枝花站 16 日流量减小为 $2000 \mathrm{~m}^{3} / \mathrm{s}$, 日均含沙量为 $0.007 \mathrm{~kg} / \mathrm{m}^{3}$, 径流基本恢复正常水平, 含沙量的大幅减小主要受金 沙江中游梯级电站拦沙作用的影响.
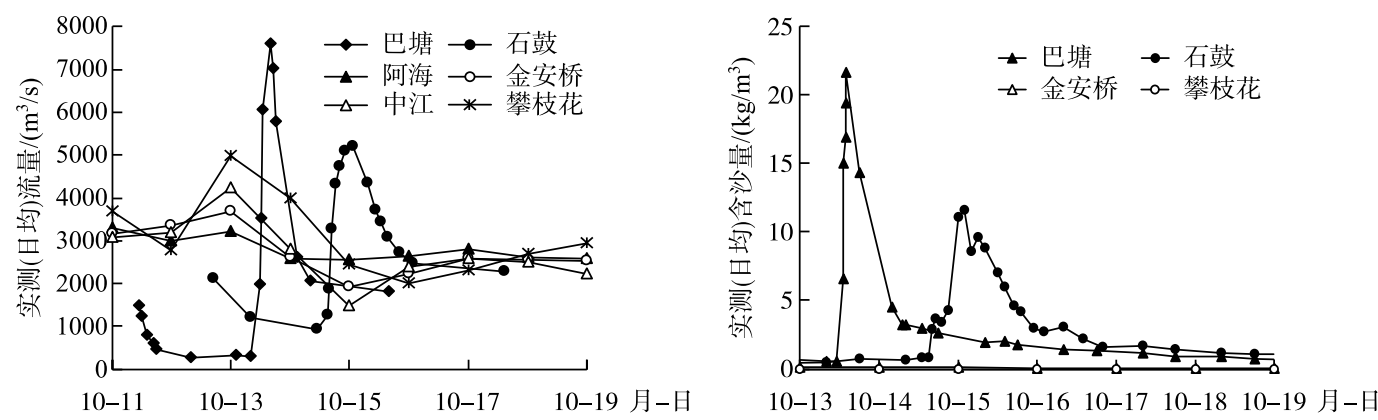

图 2 白格堰塞湖第一次泄流后洪峰和沙峰传播过程

Fig.2 Flood peak and sand peak propagation process after the first breaking of Baige landslide-dammed lake

\section{2 第二次泄洪期 (人工)}

白格堰塞湖第二次泄流经由人工挖掘的通道, 洪峰流量达万年一遇, 洪水过程传播迅速. 2018 年 11 月 13 日 18 时白格堰塞湖出现最大下泄流量 $31000 \mathrm{~m}^{3} / \mathrm{s}$, 巴塘站 14 日 1 时出现洪峰 $21200 \mathrm{~m}^{3} / \mathrm{s}$, 沙峰先于洪峰 $1 \mathrm{~h}$ 出现, 含沙量高达 $42.0 \mathrm{~kg} / \mathrm{m}^{3}$, 沙峰过程瘦尖, 含沙量大于 $5 \mathrm{~kg} / \mathrm{m}^{3}$ 的过程持续约 $11 \mathrm{~h}$. 石鼓站 15 日 8 时 出现 $8380 \mathrm{~m}^{3} / \mathrm{s}$ 洪峰, 沙峰提前洪峰 $6 \mathrm{~h}$ 出现, 含沙量为 $28.5 \mathrm{~kg} / \mathrm{m}^{3}$, 沙峰过程有所坦化, 含沙量大于 $5 \mathrm{~kg} / \mathrm{m}^{3}$ 的过程持续约 $28 \mathrm{~h}$ (图 3). 相较于自然泄流情况, 人工泄流期洪峰流量显著偏大, 洪峰传播更为迅速, 白格 至巴塘区间洪峰传播速度为 $27.1 \mathrm{~km} / \mathrm{h}$, 巴塘至石鼓区间洪峰传播速度为 $12.9 \mathrm{~km} / \mathrm{h}$. 此次泄流期间, 堰塞湖 水除挟带二次滑坡体产生的泥沙以外, 还将第一次泄流期沉积在河道内的泥沙再次冲起, 致使堰塞体下游 河道沙峰含沙量较第一次泄流期高出 1 倍, 沙峰相较于洪峰提前出现, 且高含沙量持续过程时间也有所延 长, 石鼓站高含沙量过程持续时间延长尤为明显. 11 月 $13-16$ 日期间, 巴塘至石鼓河段内总计沉积泥沙仅 95.8 万 $\mathrm{t}$,远小于第一次自然泄流期.
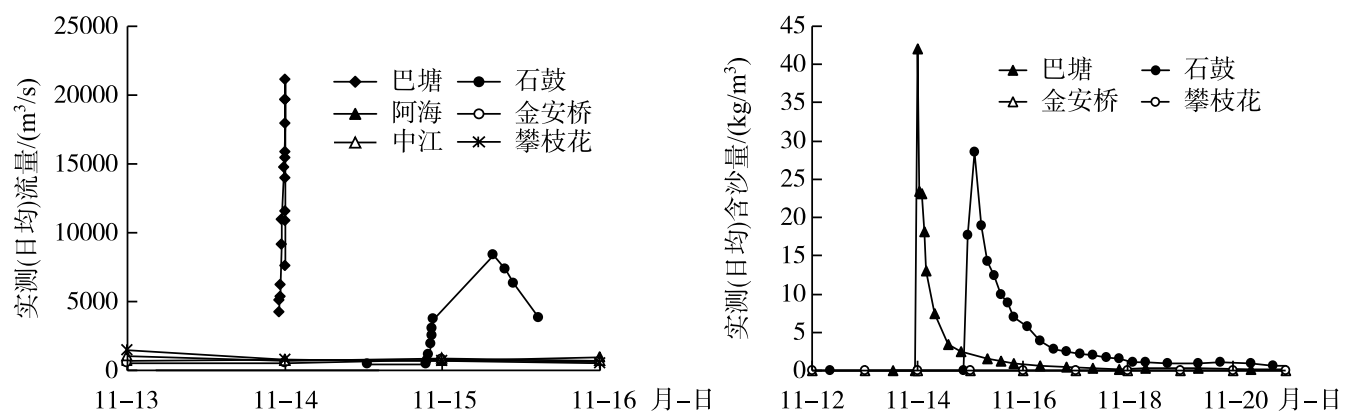

图 3 白格堰塞湖第二次泄流后洪峰和沙峰传播过程

Fig.3 Flood peak and sand peak propagation process after the second breaking of Baige landslide-dammed lake

洪峰经过石鼓站后, 开始进人金沙江中游梯级电站, 为削减洪峰,梨园、阿海和金安桥电站开展紧急调 
度, 至 12 日 14 时,金沙江中游梯级水库共腾出库容 8.07 亿 $\mathrm{m}^{3}$, 可用调节库容 13.0 亿 $\mathrm{m}^{3[8]}$, 以应对堰塞湖溃 坝洪水. 洪峰经梯级电站拦截后, 15 日阿海和金安桥站日均流量分别削减至 763 和 $796 \mathrm{~m}^{3} / \mathrm{s}$, 至攀枝花站流 量变化不大,含沙量基本小于 $0.01 \mathrm{~kg} / \mathrm{m}^{3}$.

可见,白格堰塞湖两次泄流时的洪峰和沙峰传播过程持续影响至金沙江中游, 经金沙江中游梯级电站 逐级调蓄后,至金沙江中游出口, 水沙条件基本恢复正常. 第一次泄流期间, 堰塞湖水挟带的泥沙大量在河 道内沉积下来,洪峰和沙峰几乎同步传播,传播速度沿程递减; 第二次泄流期间,洪峰流量较第一次显著偏 大, 传播过程更为迅速, 堰塞湖水将第一次泄流期间沉积于河道的大部分泥沙再次掀起挟带至下游, 沙峰先 于洪峰出现,挟带的泥沙最终在金沙江中游梯级电站内沉积下来,金沙江中游出口含沙量依然维持极低的 水平.

\section{3 对金沙江水沙条件的影响}

\section{1 对径流量及其过程的影响}

2018 年长江上游来流较往年偏丰, 尤其是汛期流量明显偏大. 在天然来流偏丰、堰塞湖溃坝洪水及梯级 电站调蓄综合作用下,金沙江中下游的年内流量过程与往年有一定差别. 具体就堰塞湖事件的影响来看,两 次堵江对干流流量的影响发展过程均可分为四个阶段, 首先是滑坡体堵江, 导致堰塞湖下游河道流量骤减, 10 月 11 日和 11 月 5 日, 堰塞湖上游岗拖站 (堰塞湖上游约 $90 \mathrm{~km}$ ) 日均流量分别为 $1320 、 670 \mathrm{~m}^{3} / \mathrm{s}$, 下游巴 塘站流量则分别减小至 $315 、 208 \mathrm{~m}^{3} / \mathrm{s}$; 其次是金沙江中游梯级水库为消纳堰塞湖水体提前预泄, 对应金沙 江中游出口攀枝花站增大, 10 月 13 日和 11 月 8 日,水库预泄使得攀枝花站日均流量分别达到 4980 和 3250 $\mathrm{m}^{3} / \mathrm{s}$; 第三阶段堰塞湖漫溢 (溃决), 下游巴塘、石鼓站流量骤增; 最后一个阶段金沙江中游梯级对堰塞湖洪 水进行调蓄, 之后金沙江中游出口流量过程恢复正常 (图 4). 可见,2018 年堰塞湖事件加大了下游金沙江干 流一段时期内的流量变幅.
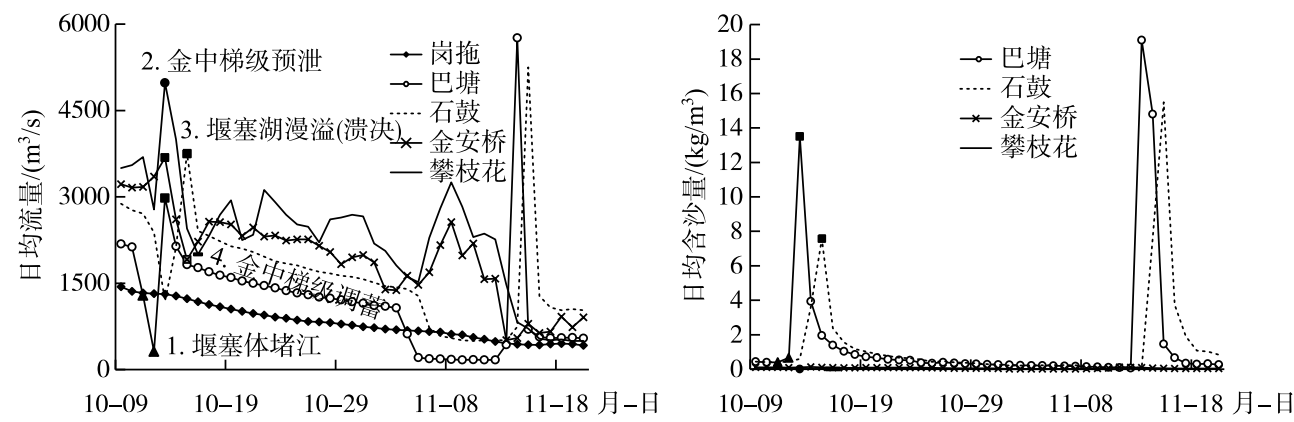

图 4 金沙江上游及中游主要站点 2018 年 10-11月日均流量、含沙量变化

Fig.4 Daily average discharge and sediment content of main stations in the upper and middle Jinsha River from October to November of 2018

进一步统计对比 1981 年以来金沙江干流控制站 10 月、11 月的径流量和最大流量(表 2),首先, 2018 年 10 月和 11 月,金沙江中下游径流量偏大主要与上游来水偏大有关,与 1981-2010 年、2011-2017 年均值相 比, 10 月岗拖站径流量分别偏大 $83.8 \%$ 和 $51.7 \%$,下游巴塘、石鼓、金安桥及攀枝花站偏大的幅度均不及岗 拖站. 其次, 堰塞湖对径流过程的影响集中体现在月最大流量的变化, 上游岗拖站 10 月、11月最大流量均未 超出 1981 年以来的最大范围,但下游巴塘至攀枝花站几乎都出现了超历史的最大流量. 可见,堰塞湖事件 并未改变金沙江中下游径流总量, 仅影响了局部时段内的径流分配. 堰塞湖事件对于其下游金沙江干流的 水流过程可以从堰塞体形成到恢复天然过流的过程进行解释, 堰塞湖形成至溃决前, 持续汇集上游来流, 汇 集的水流在溃决后一段时间内集中向下游输送,简单意义上可看作是将上游几天的来流压缩在较短的时间 内输送,导致局部时段流量骤增. 
表 2 1981－2018 年金沙江干流控制站 10-11 月径流输沙特征对比 *

Tab.2 Runoff and sediment transport of October and November in the upper and middle Jinsha River at different stages (1981-2018)

\begin{tabular}{|c|c|c|c|c|c|c|c|c|c|c|c|}
\hline \multirow{2}{*}{ 统计项目 } & \multirow{2}{*}{ 时段 } & \multicolumn{2}{|c|}{ 岗拖 } & \multicolumn{2}{|c|}{ 巴塘 } & \multicolumn{2}{|c|}{ 石鼓 } & \multicolumn{2}{|c|}{ 金安桥 } & \multicolumn{2}{|c|}{ 攀枝花 } \\
\hline & & 10 月 & 11 月 & 10 月 & 11 月 & 10 月 & 11 月 & 10 月 & 11 月 & 10 月 & 11 月 \\
\hline \multirow{3}{*}{$\begin{array}{c}\text { 月 (均) 径流量/ } \\
\left(\text { 亿 } \mathrm{m}^{3}\right)\end{array}$} & $1981-2010$ 年 & 17.5 & 7.75 & 28.4 & 13.8 & 45.3 & 23.2 & / & I & 65.6 & 33.4 \\
\hline & 2011-2017 年 & 21.2 & 9.12 & 33.2 & 15.9 & 43.9 & 22.5 & 54.4 & 30.1 & 58.7 & 32.4 \\
\hline & 2018 年 & 32.1 & 12.4 & 47.4 & 17.7 & 63.7 & 27.7 & 75.5 & 34.7 & 84.1 & 40.2 \\
\hline \multirow{3}{*}{$\begin{array}{c}\text { 月最大流量/ } \\
\left(\mathrm{m}^{3} / \mathrm{s}\right)\end{array}$} & $1981-2010$ 年 & 2050 & 820 & 2630 & 1020 & 3830 & 1780 & / & / & 5820 & 2730 \\
\hline & 2011-2017 年 & 1910 & 680 & 2530 & 977 & 3170 & 1320 & 4650 & 3000 & 4010 & 2940 \\
\hline & 2018 年 & 1840 & 745 & 7850 & 21200 & 5210 & 8380 & 5880 & 3920 & 5740 & 3890 \\
\hline \multirow{3}{*}{$\begin{array}{c}\text { 月 (均) 输沙量/ } \\
\text { (万 } \mathrm{t})\end{array}$} & $1981-2010$ 年 & & & 58.7 & 6.79 & 122 & 20.6 & / & / & 364 & 63.0 \\
\hline & $2011-2017$ & & & 70.2 & 10.0 & 120 & 20.5 & 19.7 & 4.15 & 25.7 & 11.7 \\
\hline & 2018 年 & & & 688 & 842 & 710 & 892 & 84.6 & 11.6 & 11.3 & 1.36 \\
\hline \multirow{3}{*}{$\begin{array}{c}\text { 月最大含沙量/ } \\
\left(\mathrm{kg} / \mathrm{m}^{3}\right)\end{array}$} & $1981-2010$ 年 & & & 0.995 & 0.118 & 1.09 & 1.59 & / & I & 19.6 & 1.24 \\
\hline & 2011-2017 年 & & & 0.785 & 0.126 & 0.792 & 0.224 & 2.1 & 0.049 & 0.175 & 0.277 \\
\hline & 2018 年 & & & 21.6 & 42.0 & 11.6 & 28.5 & 0.22 & 0.133 & 0.033 & 0.009 \\
\hline
\end{tabular}

* 金安桥水文站于 2004 年 1 月设立,2010 年 6 月变更领导机关后收集相关数据,/表示无数据.

综上,2018 年 10 月和 11 月金沙江中游控制站的径流量偏大主要与上游来流量偏丰有关, 白格堰塞湖 对流量过程的影响,主要体现为堰塞体汇聚上游几天来流后在溃决时集中向下游输送,导致局部时段流量 骤增, 自巴塘至攀枝花 10 月、 11 月最大流量大多超过历史最大值. 特大洪水经金沙江中游梨园、阿海和金安 桥电站联合调度后, 到达下游阿海、金安桥站已削减为正常洪水, 至金沙江中游出口攀枝花站, 流量过程变 化不明显.

\section{2 对输沙量及其过程的影响}

据许强等的研究, 2018 年 10 月第一次滑坡体的体积约有 2200 万 $\mathrm{m}^{3}$, 岩土体失稳堵塞金沙江后形成堰 塞坝; 11 月第二次滑坡总体积达 930 万 $\mathrm{m}^{3[9]}$. 综合邓建辉等的研究成果,估算出两次滑坡堆积至金沙江河 道内的土体体积在约 3200 万 $\mathrm{m}^{3[5,9]}$, 若按土体干容重 $1.65 \mathrm{t} / \mathrm{m}^{3}$ 计算, 进人河道内的土体总计约 5300 万 $\mathrm{t}$. 泥 沙进人河道后, 部分随水流向下游输移并沿程沉积下来, 直至进人金沙江中游梯级电站被拦截, 至金沙江出 口,泥沙输移强度恢复至正常水平. 因此,白格堰塞湖事件产生的大量泥沙可能分布在 3 个区域,一是仍留 在堰塞湖区域,二是短暂沉积在堰塞湖下游至石鼓段的河道内,三是进人金沙江中游梯级水库. 下文拟研究 给出滑坡体产生的泥沙在这 3 个区域的分配情况.

3.2.1 泥沙输移总量变化及其分配区域 自滑坡土体进人河道开始,泥沙便由水体挟带在河道内输移并持续 相当长的一段时间,统计 2018 年 10 月 11 日至 11 月 30 日期间 (2018 年 12 月至 2019 年 3 月枯水期间,金沙 江上游和中游水文控制站均不开展泥沙观测), 金沙江干流的径流、输沙总量如表 3. 上游岗拖站不开展泥沙 观测, 据此前的泥沙观测资料,估算这一时段内该站输沙量总和不超过 20 万 t. 同期,巴塘站的泥沙输移量 多达 1420 万 $\mathrm{t}$, 在不考虑区间产沙情况下, 可以认为较岗拖站多出的 1400 万 $\mathrm{t}$ 为滑坡事件产生的泥沙. 巴塘 至石鼓段河道内泥沙仅在泄流期间短暂沉积, 随后被水流逐渐挟带至下游, 因而巴塘站与石鼓站的输沙量 基本相当, 且巴塘站在堰塞湖期间断面主河槽部分呈冲刷下切状态 (图 5a), 也就是说河道内并未有泥沙沉 积的现象, 反而冲刷补充约 30 万 $\mathrm{t}$ 的泥沙. 可见, 堰塞湖区域和河道冲起补给的泥沙全部进人金沙江中游梯 级水库内,其中梨园、阿海和金安桥累积拦截泥沙约 1400 万 $\mathrm{t}$, 龙开口、鲁地拉和观音岩共计拦截泥沙约 43 万 $\mathrm{t}$.

再次对比各控制站 2018 年、2011-2017 年同期的平均径流量和输沙量 (表 3), 可以看出,沿程径流量 增加的规律没有发生变化, 堰塞湖区域上游的岗站拖和下游的巴塘站, 2018 年 10 月 11 日至 11 月 30 日的 径流量较 2011-2017 年同期均值均偏大约 8 亿 $\mathrm{m}^{3}$,进一步说明堰塞湖期间径流量偏大主要与上游来流偏 

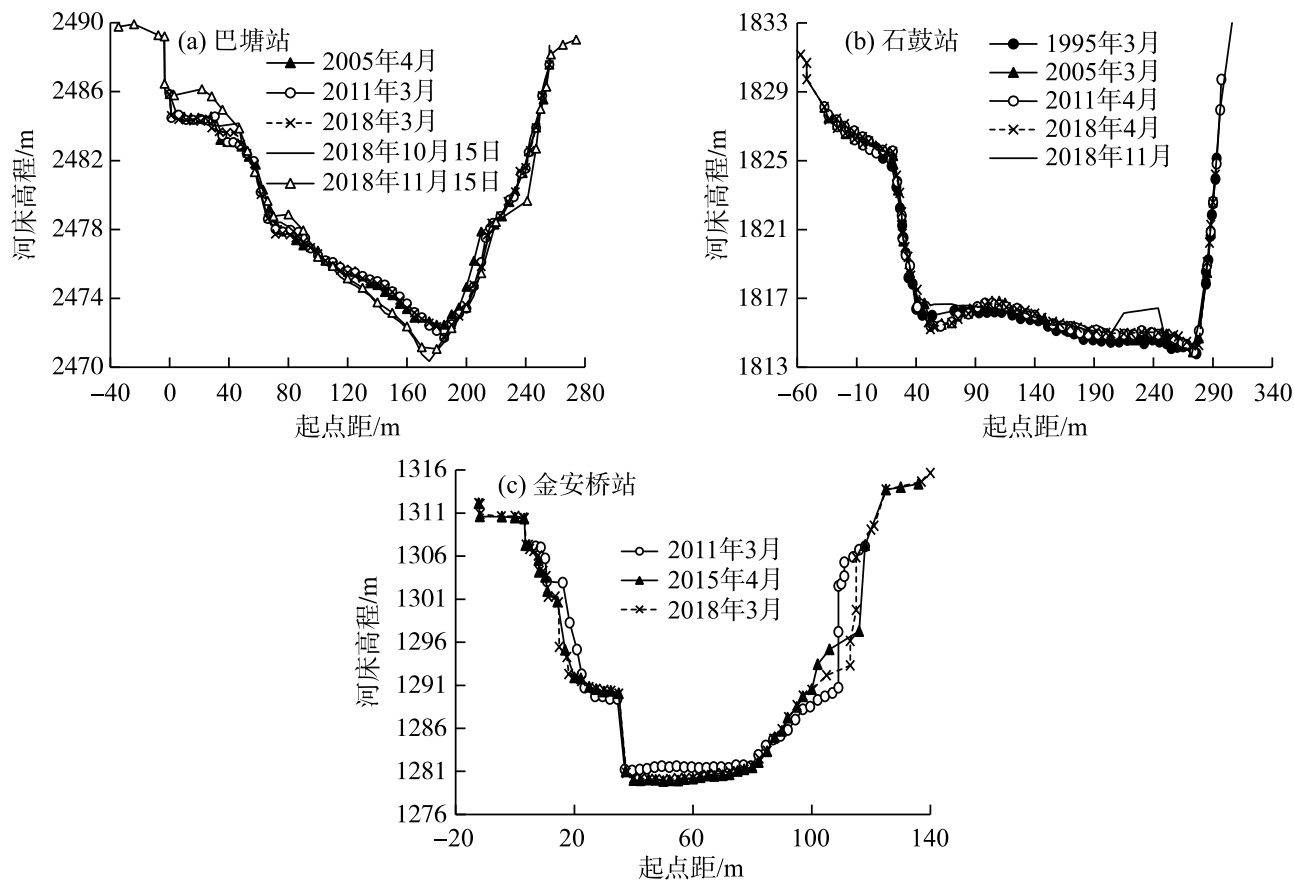

图 5 金沙江中下游水文控制站断面变化

Fig.5 Cross section change of hydrological control stations in the middle and lower reaches of Jinsha River

丰有关. 从输沙情况来看,在不考虑区间来沙的情况下,2011-2017 年同期,金沙江中游的输沙量均较小,巴 塘至石鼓段在天然情况下呈现微冲的状态, 与控制断面的变化一致(图 5), 且冲刷量略大于堰塞湖期间. 进 人并淤积在梨园、阿海和金安桥水库的沙量年均只有 61.4 万 $\mathrm{t}$, 远远小于堰塞湖溃决造成的泥沙堆积量. 上 游梯级电站拦沙作用下,龙开口、鲁地拉及观音岩电站几乎无泥沙堆积,位于库区范围内的金安桥水文站断 面自电站运行来基本无变化 (图 5c), 这也显著区别于堰塞湖期间的泥沙淤积现象.

表 3 金沙江上中游干流控制站径流、输沙量统计

Tab.3 Runoff and sediment transport of hydrological stations in the upper and middle reaches of Jinsha River

\begin{tabular}{|c|c|c|c|c|c|c|c|c|c|}
\hline 指标 & 时段 & 岗拖 & 巴塘 & 石鼓 & 金安桥 & 攀枝花 & $\begin{array}{c}\text { 巴塘一石鼓 } \\
\text { (河道) }\end{array}$ & $\begin{array}{c}\text { 石鼓一金安桥 } \\
\text { (梨、阿、金) }\end{array}$ & $\begin{array}{c}\text { 金安桥一攀枝花 } \\
\text { （龙、鲁、观） }\end{array}$ \\
\hline 径流量/ & $2018-10-11-2018-11-30$ & 30.8 & 44.6 & 64.7 & 78.7 & 91.1 & 20.1 & 14.0 & 12.4 \\
\hline$\left(\right.$ 亿 $\left.\mathrm{m}^{3}\right)$ & 2011－2017 年同期平均 & 22.7 & 36.7 & 48.7 & 63.0 & 68.0 & 12.0 & 14.3 & 5.0 \\
\hline 输沙量/ & $2018-10-11-2018-11-30$ & $20.0^{*}$ & 1420 & 1450 & 48.0 & 5.06 & -30.0 & 1402.0 & 42.9 \\
\hline$($ 万 $\mathrm{t})$ & 2011－2017 年同期平均 & / & 37.2 & 72.5 & 11.1 & 26.5 & -35.3 & 61.4 & -15.4 \\
\hline
\end{tabular}

* 表示数据为估算值, / 表示无数据.

综上,截至 2018 年 11 月 30 日,白格滑坡事件产生并输人河道的总沙量并未在河道内沉积,泥沙主要分 布在两个区域内,一是输移至金沙江中游梯级水库内,约有 1400 万 $\mathrm{t}$, 约占滑坡体总量的 $26 \%$; 二是仍留存 在堰塞湖至巴塘区间内,堆积在两岸和河床上, 滞留总量约 3900 万 $\mathrm{t}$, 约占滑坡体总量的 $74 \%$. 进一步分析 金沙江中下游干流控制站的断面变化发现, 自然情况下,金沙江中游河道河床微冲 (图 5), 巴塘站和石鼓站 的断面长久以来都没有出现泥沙堆积的现象. 可以认为在一定的来流条件下,金沙江上中游河道具备将堆 积在河道内的滑坡土体向下游输移的能力. 因而,水流以河床掀起和河岸侵蚀等形式,持续将滑坡体泥沙向 下游输移, 今后几年的汛期堰塞湖下游河道仍将会出现大含沙量水流, 大部分泥沙最终会沉积在金沙江中 
游的梯级水库内.

进一步从石鼓站在堰塞湖泄流期间的悬移质泥沙颗粒组成情况来看 (图 6), 堰塞湖泄流期间, 石鼓站多 出的悬移质泥沙中颗粒小于 $0.125 \mathrm{~mm}$ 的沙量百分比超过 $93 \%$, 悬移质泥沙中值粒径未超出 2010 年以来的 平均值, 表明滑坡体产生的较细的泥沙颗粒随水流迅速输移至下游, 而粗颗粒的泥沙或块石则以推移质形 式运动,输移速度相对较慢. 据统计, 1981-2017 年巴塘和石鼓站多年平均年输沙量分别为 2030 万 $\mathrm{t}$ 和 2850 万 $\mathrm{t}$, 表明巴塘至石鼓区间水流仍有年均约 800 万 $\mathrm{t}$ 泥沙挟带能力富余. 且巴塘和石鼓大断面资料显示 该河段内长期没有出现泥沙沉积的现象,因此该段泥沙输移富余能力远远超过 800 万 t. 参照金沙江下游的 产输沙特点来看, 该区段崩塌、滑坡、泥石流等重力侵蚀量大, 仅干流河谷区间年侵蚀量即达 0.76 亿 $\mathrm{t}^{[13]}$, 这 部分重力侵蚀物质大多直接进人河道形成河道泥沙 ${ }^{[14]}$. 金沙江上游落差大、水流流速大, 且含沙量一直较 小, 水流对河床和两岸都有较强的侵蚀作用. 因此, 在过流的情况下, 此次白格滑坡事件产生并堆积在河道 内的土体都能随水流输移至河道下游, 再结合河道的实际输沙能力简单估算, 堰塞湖区滞留的悬移质泥沙 将集中在今后约 5 年的汛期输移,推移质泥沙的输移过程则相对漫长.

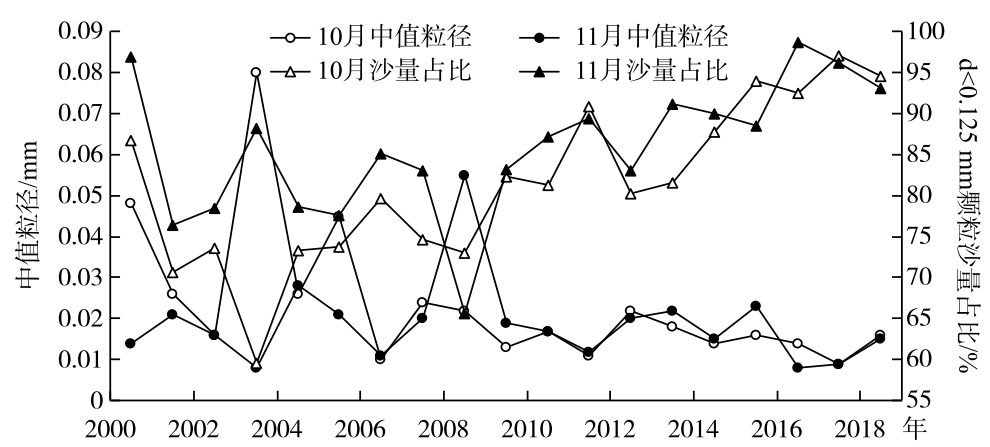

图 6 石鼓站 10、11 月中值粒径及 $\mathrm{d}<0.125 \mathrm{~mm}$ 泥沙颗粒沙量百分比年际变化

Fig.6 Anually changes of median diameter and percentage of suspended sediment with the diameter below $0.125 \mathrm{~mm}$ in October and November at Shigu station

3.2.2 泥沙输移过程的变化特征 2018 年金沙江上游汛期径流较往年明显偏丰,根据观测资料分析,金沙江 干流具有较为明显的 “大水带大沙” 特征, 历史上巴塘站和石鼓站月均含沙量极大值几乎都出现在主汛期 内, 两站的水沙输移相关关系没有出现趋势性的变化 (图 7),2018 年 7-11 月输沙量较往年偏多明显. 尤其 是 2018 年 11 月,受堰塞湖泄流的影响,巴塘和石鼓站输沙量和含沙量均异常偏大, 其月均流量一输沙率相 关关系较自然状态下明显偏离, 且输沙主要集中在沙峰期, 峰值均显著超过历史水平 (图 4, 表 2). 巴塘站两 次泄流带来的沙峰过程输沙总量分别为 488 万、 817 万 $\mathrm{t}$, 分别占 10 月、11 月输沙总量的 $70.9 \% 、 90.0 \%$. 尽管 泥沙被金沙江梨园、阿海和金安桥电站大幅拦截,但期间金安桥站输沙量仍较往年明显偏多,再经龙开口、 鲁地拉和观音岩电站到达攀枝花站, 泥沙则基本被彻底拦截. 因此, 堰塞湖泄流造成下游河道出现集中输水 输沙的现象, 且影响范围主要在金沙江中游, 金沙江中游的梯级电站截断了这种影响, 使得金沙江下游水沙 基本不受影响.

可见,白格堰塞体泄流向下游集中输送了大量的泥沙, 下游巴塘、石鼓站 10 月、11 月输沙量显著偏多, 且主要集中在泄流期间输移. 截至目前, 堰塞湖下游河道河床未出现泥沙堆积现象, 白格滑坡堆积至河道内 的泥沙约有 $26 \%$ 输送至金沙江中游, 经梨园、阿海、金安桥、龙开口、鲁地拉、观音岩等水电站库区,约 $74 \%$ 的 泥沙仍滞留在堰塞湖区域和巴塘上游河道内. 受金沙江中游梯级调蓄和拦沙作用,金沙江中游出口攀枝花 站径流过程变化较小, 输沙量仍延续 2011 年以来较正常偏少的规律. 因此, 堰塞湖形成及泄流对金沙江水 沙的影响基本在上中游段范围内. 

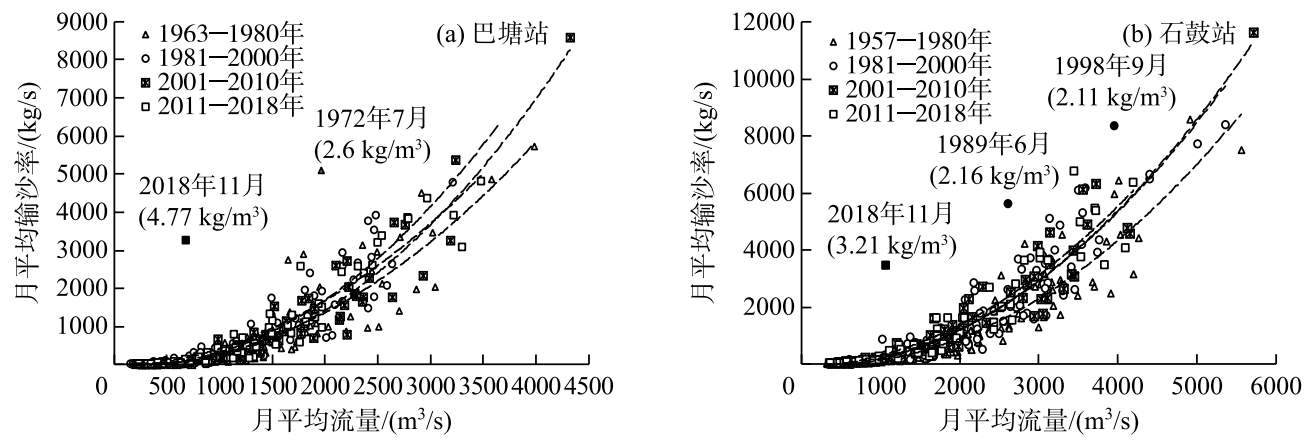

图 7 金沙江中游巴塘和石鼓站月均流量一输沙率的相关关系

Fig.7 Average monthly flow and sediment relationship of Batang and Shigu stations in the middle reaches of Jinsha River

\section{4 对金沙江梯级水电站运行的影响}

\section{1 金沙江中下游梯级电站调度情况}

2012 年 7 月,国家发改委批复了金沙江上游规划“一库十三级”的水电开发方案,其中自白格堰塞湖往 下游分别为叶巴滩、拉哇、巴塘、苏洼龙、昌波、旭龙和奔子栏水电站, 叶巴滩 (预计 2025 年建成)、巴塘 (预计 2023 年建成) 和苏洼龙 (预计 2021 年建成) 已开工建设. 金沙江中游水电开发规划方案为“一库八级”, 目前 上虎跳峡和两家人尚未开工建设, 已建成的第一个电站为梨园, 其下游依次是阿海、金安桥、龙开口、鲁地 拉、观音岩电站, 金沙江下游已建成的梯级主要是溪洛渡和向家坝电站, 电站相对位置分布如图 1 , 金沙江中 下游已建成运行的水电站各项基本指标如表 4 . 金沙江中游 6 级和下游 2 级电站从 2010 年开始陆续蓄水运 行, 2015 年均建成完工. 金沙江中游 6 级电站的总调节库容约 16.38 亿 $\mathrm{m}^{3}$, 正常蓄水位以下的总库容为 65.99 亿 $\mathrm{m}^{3}$,其中,梨园电站调节库容和正常蓄水位以下库容分别为 1.73 亿 $\mathrm{m}^{3}$ 和 5.54 亿 $\mathrm{m}^{3}$.

表 4 已建金沙江中下游梯级电站基本指标统计

Tab.4 Basic indicators of cascade reservoirs in the middle and lower reaches of Jinsha River

\begin{tabular}{|c|c|c|c|c|c|c|c|c|}
\hline 指标 & 梨园 & 阿海 & 金安桥 & 龙开口 & 鲁地拉 & 观音岩 & 溪洛渡 & 向家坝 \\
\hline \multirow{3}{*}{$\begin{array}{c}\text { 正常蓄水位/m } \\
\text { 死水位/m } \\
\text { 汛限水位/m }\end{array}$} & 1618 & 1504 & 1418 & 1298 & 1223 & 1134 & 600 & 380 \\
\hline & 1605 & 1492 & 1398 & 1290 & 1216 & 1122 & 540 & 370 \\
\hline & 1605 & 1493.3 & 1410 & 1289 & 1212 & $1122.3 / 1128.8$ & 560 & 370 \\
\hline \multirow{2}{*}{$\begin{array}{c}\text { 调节库容/ }\left(\text { 亿 } \mathrm{m}^{3}\right) \\
\text { 死库容/ }\left(\text { 亿 } \mathrm{m}^{3}\right)\end{array}$} & 1.73 & 2.38 & 3.46 & 1.13 & 3.85 & 3.83 & 64.6 & 9.03 \\
\hline & 5.54 & 5.68 & 5.01 & 3.94 & 12.55 & 16.89 & 51.1 & 40.7 \\
\hline 防洪库容/ $\left(\right.$ 亿 $\left.\mathrm{m}^{3}\right)$ & 1.73 & 2.15 & 1.58 & 1.26 & 5.64 & $5.42 / 2.53$ & 46.5 & 9.03 \\
\hline \multirow[t]{2}{*}{ 建设情况 } & 2014 年 11 月 & 2012 年 12 月 & 2010 年 & 2012 年 11 月 & 2013 年 5 月 & 2014 年 10 月 & 2013 年 5 月 & 2012 年 10 月 \\
\hline & 2015 年 11 月 & 2014 年 5 月 & 2012 年 & 2014 年 1 月 & 2015 年 & 2015 年 & 2015 年 & 2015 年 \\
\hline
\end{tabular}

2018 年白格堰塞湖第一次自然泄流前梨园、阿海和金安桥水库共腾出近 3 亿 $\mathrm{m}^{3}$ 库容接纳堰塞湖洪水, 洪峰出阿海电站后基本恢复至正常状态. 第二次人工泄流前, 根据险情发展和工程措施降低堰塞体高程进 展情况, 长江水利委员会提出分堰塞体溃决前和溃决后两阶段四步走的腾库实施方案, 优先使用梨园、阿 海、金安桥水库拦蓄洪水,分阶段对水库进行调度,降低梨园、阿海、金安桥水库水位分别至 1592.0、1493.3、 $1406.0 \mathrm{~m}$, 累计腾空库容约 13 亿 $\mathrm{m}^{3}$. 通过水库拦蓄, 努力将堰塞体溃坝洪水消纳在金沙江中游, 并全力保障 水库安全. 2018 年 11 月 16 日,金沙江“ 11.3 ” 白格堰塞湖溃坝洪水通过梨园水库,最大人库流量 $7410 \mathrm{~m}^{3} / \mathrm{s}$, 最大出库流量 $4490 \mathrm{~m}^{3} / \mathrm{s}$, 削减洪峰流量 $2920 \mathrm{~m}^{3} / \mathrm{s}$; 阿海水库承接上游梨园水库下泄流量, 最大人库流量 $4430 \mathrm{~m}^{3} / \mathrm{s}$, 最大出库流量 $2900 \mathrm{~m}^{3} / \mathrm{s}$, 削减洪峰流量 $1530 \mathrm{~m}^{3} / \mathrm{s}$ (图 8), 梯级电站联合调度作用下, 将金沙江 


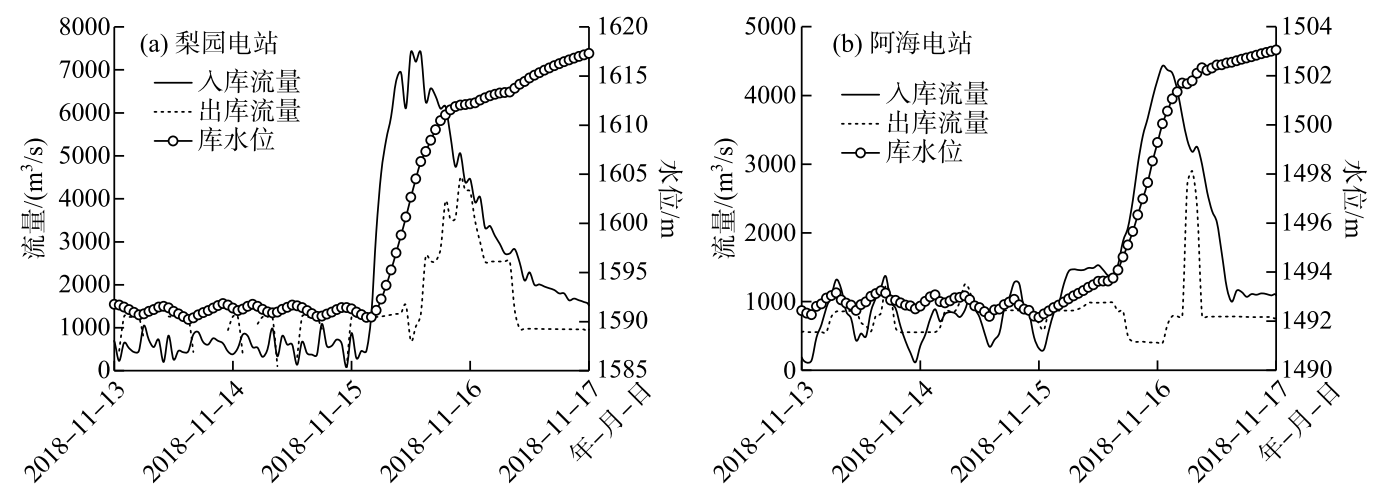

图 8 白格堰塞湖第二次泄流期间金沙江中游梨园、阿海电站的调度情况

Fig. 8 Dispatching of Liyuan and Ahai hydropower stations during the second discharge period of Baige landslide-dammed lake

上游万年一遇洪水逐步削减为一般洪水 ${ }^{[6]}$. 金沙江干流 “大水带大沙” 的现象十分明显, 水库在削减大洪水 的同时,也拦截了大量的泥沙, 从而对水库运行及使用寿命带来一定的影响.

\section{2 对金沙江梯级电站运行的影响}

考虑到金沙江上游梯级电站均尚未建成运行, 此次堰塞湖事件, 发挥削减洪峰作用和拦截泥沙的电站 主要是金沙江中游的梨园和阿海电站, 且泥沙拦截以梨园电站为主, 因此, 关于堰塞湖事件对于金沙江梯级 电站运行的影响分析主要围绕梨园电站开展. 梨园电站于 2014 年 11 月蓄水, 2015 年 11 月建成投产. 根据 《金沙江中游河段梨园水电站可行性研究报告》, 电站在可行性研究阶段给出的坝址多年平均悬移质输沙量 为 2821 万 $\mathrm{t}$, 推移质输沙量为 84.6 万 $\mathrm{t}$, 输沙量较大, 因而就是否设置汛期排沙水位开展了专项研究. 研究认 为若无上游规划的两家人和虎跳峡电站, 梨园电站工程的泥沙问题较为严重, 在水库单独运行的条件下, 泥 沙淤积 5 年或 10 年后剩余有效库容能满足水库所需调节库容的要求, 20 年后不满足要求.

梨园电站目前已蓄水运行 4 年多,上游两家人和虎跳峡电站尚未开工. 按照金沙江干流控制水文站的输 沙量初步统计, 2015-2018 年, 梨园、阿海和金安桥电站共计拦截泥沙约 8606 万 $\mathrm{t}$,年均拦沙量为 2150 万 $\mathrm{t}$, 按 泥沙容重换算后占 3 个梯级正常蓄水位以下库容的比例约 $2.2 \%$, 且在这 3 级电站中, 以梨园电站拦沙为主. 除 2015 年以外, 2016、2017 和 2018 年梨园电站坝址(采用石鼓站, 考虑区间产沙后, 实际坝址的输沙来量应 较石鼓站偏大) 的悬移质泥沙淤积量均较可研阶段采用值偏大, 尤其是 2018 年, 偏大幅度达到 $87 \%$, 且堰塞 湖下游河道长期处于补给泥沙的状态, 金沙江上游的梯级电站最早也将于 2021 年建成, 堰塞湖区域滞留的 约 3900 万 $\mathrm{t}$ 的泥沙大多将陆续输移至金沙江中游梯级水库内 (表 5). 在这种情况下, 梨园电站单独运行 5 年或者 10 年剩余的有效库容有可能不满足水库所需调节库容的要求.

表 5 2015-2018 年金沙江中游梯级电站蓄水以来拦沙情况统计

Tab.5 Reservoir trapping amount in the middle reaches of Jinsha River from 2015 to 2018

\begin{tabular}{|c|c|c|c|c|c|c|c|c|}
\hline \multirow{2}{*}{ 时间 } & \multicolumn{4}{|c|}{ 年输沙量/(万 t) } & \multicolumn{2}{|c|}{ 水库联合拦沙量/(万 t) } & \multicolumn{2}{|c|}{ 占正常蓄水以下的比例 $/ \%$} \\
\hline & 巴塘 & 石鼓 & 金安桥 & 攀枝花 & 梨、阿、金 & 龙、鲁、观 & 梨、阿、金 & 龙、鲁、观 \\
\hline 2015 年 & 764 & 1190 & 401 & 256 & 789 & 145 & 0.20 & 0.02 \\
\hline 2016 年 & 1290 & 2860 & 846 & 553 & 2014 & 293 & 0.51 & 0.04 \\
\hline 2017 年 & 2300 & 3200 & 767 & 323 & 2433 & 444 & 0.62 & 0.06 \\
\hline 2018 年 & 4420 & 5290 & 1920 & 339 & 3370 & 1581 & 0.86 & 0.23 \\
\hline 合计 & 8774 & 12540 & 3934 & 1471 & 8606 & 2463 & 2.2 & 0.35 \\
\hline
\end{tabular}

2018 年, 金沙江下游已经建成运行的溪洛渡和向家坝电站均于白格滑坡事件发生前 (9 月 30 日) 完成 
蓄水任务, 同时白格堰塞湖事件产生的大量泥沙被金沙江中游梯级电站拦截, 至金沙江下游人口攀枝花站, 水沙过程基本未受影响. 因此,白格堰塞湖对金沙江下游梯级水库人库水沙条件和水库运行基本无影响.

\section{5 结论}

本文从堰塞湖泄流对洪峰、沙峰传播过程出发, 对比分析了金沙江上游、中游控制站的流量和输沙量及 其变化过程, 结合金沙江中游梯级电站的调度情况, 评估了堰塞湖事件对金沙江中下游水沙输移及梯级电 站运行的影响, 主要结论如下:

1) 2018 年 10 月和 11 月堰塞湖两次泄流溃口附近最大流量分别为 10000 和 $31000 \mathrm{~m}^{3} / \mathrm{s}$, 洪峰和沙峰传 播过程持续影响至金沙江中游, 自巴塘站至攀枝花站月最大流量、最大含沙量多数超过历史最大值. 堰塞湖 溃决洪水经金沙江中游梯级电站逐级调蓄后,至金沙江中游出口,水沙条件基本恢复正常. 自然泄流期洪峰 和沙峰基本同步传播, 人工泄流期洪峰流量较自然泄流期显著偏大, 传播过程更为迅速, 并将自然泄流期间 沉积于河道的大部分泥沙再次掀起挟带至下游, 沙峰先于洪峰出现.

2) 白格两次滑坡堆积至金沙江河道内的土体体积约 5300 万 t. 堰塞湖溃决后,滑坡体产生的较细的泥 沙颗粒随水流迅速输移至下游, 巴塘至石鼓河段河床未出现泥沙堆积的现象, 泥沙主要输移并沉积在金沙 江中游梯级水电站内, 其中梨园、阿海和金安桥累积拦截泥沙约 1400 万 $\mathrm{t}$, 龙开口、鲁地拉和观音岩共计拦 截泥沙约 43 万 $\mathrm{t}$, 梯级水库拦截泥沙量约占滑坡土体总量的 $26 \%$. 余下 $74 \%$ 的泥沙仍滞留在堰塞湖区域和 巴塘以上河道内, 滞留的悬移质泥沙将集中在今后约 5 年的汛期输移, 推移质泥沙的输移过程则相对漫长.

3) 除 2015 年以外,2016、2017 和 2018 年梨园电站坝址的悬移质泥沙淤积量均较可研阶段采用值偏大, 2018 年偏大幅度达到 $87 \%$. 加之堰塞湖下游河道长期处于补给泥沙的状态, 金沙江上游梯级电站最早将于 2021 年开始陆续建成, 堰塞湖区域滞留的泥沙大多陆续输移至金沙江中游梯级水库内,梨园电站单独运行 5 年或者 10 年剩余的有效库容有可能不满足水库所需调节库容的要求.

\section{6 参考文献}

[ 1 ] Xu QX, Shi GY, Chen ZF. Analysis of recent changing characteristics and tendency runoff and sediment transport in the upper reach of Yangtze River. Advance in Water Science, 2004, 15(4) : 420-426. [许全喜, 石国钰, 陈泽方. 长江上游 近期水沙变化特点及其趋势分析. 水科学进展, 2004, 15(4): 420-426.]

[ 2 ] Wei J, He XB. The impacts of human activities on riverine sediment load: A case study of the Upper Yangtze River Basin. Geographical Research, 2012, 31(12) : 2259-2269. [韦杰, 贺秀斌. 流域侵蚀产沙人类活动影响指数研究一一以长 江上游为例. 地理研究, 2012, 31(12): 2259-2269.]

[ 3 ] Chen QB, Wang KQ, Li YM et al. Effect of different vegetation types on soil amelioration in dry-hot valley of Jinshajiang River Basin. Journal of Soil and Water Conservation, 2003, 17(2): 67-70. [陈奇伯, 王克勤, 李艳梅等. 金沙江干热 河谷不同类型植被改良土壤效应研究. 水土保持学报, 2003, 17(2): 67-70.]

[ 4 ] Chen SS, Zhang OY, Chen ZF et al. Variation of runoff and sediment load of the Jinsha River. Advance in Water Science, 2008, 19(4) : 475-482. [陈松生, 张欧阳, 陈泽方等. 金沙江流域不同区域水沙变化特征及原因分析. 水科学进 展, 2008, 19(4): 475-482.]

[ 5 ] Deng JH, Gao YJ, Yu ZQ et al. Analysis on the formation mechanism and process of Baige landslides damming the upper reach of Jinsha River, China. Advanced Engineering Sciences, 2019, 51(1): 9-16. [邓建辉, 高云建, 余志球等. 堰塞 金沙江上游的白格滑坡形成机制与过程分析. 工程科学与技术, 2019, 51(1):9-16.]

[ 6 ] Feng WK, Zhang GQ, Bai HL et al. A preliminary analysis of the formation mechanism and development tendency of the huge Baige landslide in Jinsha River on October 11, 2018. Journal of Engineering Geology, 2019, 27(2) : 415-425. [冯 文凯, 张国强, 白慧林等. 金沙江“10・11” 白格特大型滑坡形成机制及发展趋势初步分析. 工程地质学报, 2019, 27(2) : 415-425.]

[ 7 ] Cheng HY. Hydrology emergency monitoring and forecast on “11·3” Baige barrier lake, Jinsha River. Yangtze River, 2019，50(3) : 23-27，39. [程海云. “11·3” 金沙江白格堰塞湖水文应急监测预报. 人民长江, 2019，50(3)：23$27,39$.

[ 8 ] Chen M. Experiences and inspirations of reservoir regulation in urgent treatment of Baige barrier lake on Jinsha River. Yan- 
gtze River, 2019, 50(3) : 10-14. [ 陈敏. 金沙江白格堰塞湖处置中水库应急调度经验与启示. 人民长江, $2019, \mathbf{5 0}$ (3) : 10-14.]

[ 9 ] Xu Q, Zheng G, Li WL et al. Study on successive landslide damming events of Jinsha River in Baige Village on October 11 and November 3, 2018. Journal of Engineering Geology, 2018, 26(6) : 1534-1551. [许强, 郑光, 李为乐等. 2018 年 10 月和 11 月金沙江白格两次滑坡一一堰塞堵江事件分析研究. 工程地质学报, 2018, 26(6) : 1534-1551.]

[10] Wang M, Lu JY, Yao SM et al. Study on dam break of flood forecast error and improvement for Baige barrier lake on Jinsha Rive. Yangtze River, 2019, 50(3) : 34-39. [王敏, 卢金友, 姚仕明等. 金沙江白格堰塞湖溃决洪水预报误差与改 进. 人民长江, 2019, 50(3) : 34-39.]

[11] Yuan J, Xu QX. Sediment trapping effect by reservoirs in the Jinsha Rvier basin. Advance in Water Science, 2018, 29(4): 482-491. [袁晶, 许全喜. 金沙江流域水库拦沙效应. 水科学进展, 2018, 29(4) : 482-491.]

[12] Chen J, Li YT, Deng JY et al. Influence on deposition of the Three Gorges Reservoir caused by the change of water silt conditions. Journal of Hydroelectric Engineering, 2008, 27(2): 97-102. [陈建, 李义天, 邓金运等. 水沙条件变化对 三峡水库泥沙淤积的影响. 水力发电学报, 2008, 27(2): 97-102.]

[13] Yu JR, Shi LR, Feng MH et al. The surface erosion and fluvial silt in the upper reaches of Changjiang River. Bulletin of Soil and Water Conservation, 1991, 11(1) : 9-17. [余剑如, 史立人, 冯明汉等. 长江上游的地面侵蚀与河流泥沙. 水土保持通报, 1991, 11(1): 9-17.]

[14] Liu SQ, Chen ZJ, Chen GJ et al. Surface erosion and fluvial silt in the jinsha river watershed. Resources and Environment in the Yangtze Basin, 1999, 8(4) : 423-428. [刘邵权, 陈治谏, 陈国阶等. 金沙江流域水土流失现状与河道泥沙分 析. 长江流域资源与环境, 1999, 8(4): 423-428.] 